Article

\title{
Antibacterial Evaluation, In Silico Characters and Molecular Docking of Schiff Bases Derived from 5-aminopyrazoles
}

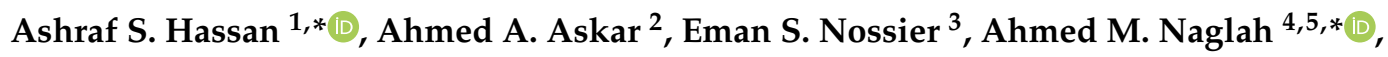 \\ Gaber O. Moustafa ${ }^{5}$ and Mohamed A. Al-Omar ${ }^{4}$ (D) \\ 1 Organometallic and Organometalloid Chemistry Department, National Research Centre, Dokki, \\ Cairo 12622, Egypt \\ 2 Botany and Microbiology Department, Faculty of Science (Boys), Al-Azhar University, Cairo 11751, Egypt \\ 3 Department of Pharmaceutical Chemistry, Faculty of Pharmacy (Girls), Al-Azhar University, \\ Cairo 11754, Egypt \\ 4 Department of Pharmaceutical Chemistry, Drug Exploration and Development Chair (DEDC), \\ College of Pharmacy, King Saud University, Riyadh 11451, Saudi Arabia \\ 5 Peptide Chemistry Department, National Research Centre, Dokki, Cairo 12622, Egypt \\ * Correspondence: ashraf_salmoon@yahoo.com (A.S.H.); anaglah@ksu.edu.sa (A.M.N.); \\ Tel.: +20-100-664-5444 (A.S.H.); +966-56-200-3668 (A.M.N.)
}

Received: 3 August 2019; Accepted: 24 August 2019; Published: 28 August 2019

check for updates

\begin{abstract}
A series of Schiff bases 14-25 were designed and synthesized for evaluation of their antibacterial properties against multi-drug resistant bacteria (MDRB). The antibacterial activities of Schiff bases 14-25 showed that most of the synthesized compounds displayed a significant antibacterial activity. Assessment of in silico ADMET properties (absorption, distribution, metabolism, excretion and toxicity) of Schiff bases illustrates that all derivatives showed agreement to the Lipinski's rule of five. Further enzymatic assay aided by molecular docking study demonstrated that compound $\mathbf{1 8}$ is a potent inhibitor of staphylococcus aureus DNA gyrase and dihydrofolate reductase kinases. This study could be valuable in the discovery of new potent antimicrobial agents.
\end{abstract}

Keywords: Schiff bases; Antibacterial; 5-Aminopyrazole; Staphylococcus aureus DNA gyrase; Dihydrofolate reductase; Molecular docking

\section{Introduction}

Antibiotics, anti-microbial drugs, and anti-infectious agents are used for treating infectious with micro-organism diseases and able to kill or inhibit the growth of microbes by inhibition of cell membranes synthesis, protein synthesis, nucleic acid synthesis, or cytoplasmic membranes. Recently, the resistance of microbes to antibiotics can be observed and classified into internal resistance and acquired resistance. Inactivation of drugs by bacterial enzymes or the drug cannot bind are the reasons which explained the biochemical mechanisms of internal and acquired resistances. Therefore, there is an urgent need for production of new antimicrobial drugs or develop the used drugs to oppose the mutation of the microbes to solve the resistance.

Schiff bases (bearing imine or azomethine- $\mathrm{C}=\mathrm{N}-$ ) have shown a broad spectrum of activities including anti-diabetic, enzyme inhibition, DNA binding, cleavage activity and cytotoxicity activities [1-6]. Additionally, there are several reports that highlight the importance of Schiff bases as antimicrobial agents [7-11]. Compound $\mathbf{1}$ demonstrated significant antibacterial activity against $S$. aureus and E. faecalis [12]. Compound 2 showed good antimicrobial activity against B. subtilis, P. fluorescence, and S. aureus [13]. Also, compound 3 exhibited better antimicrobial activity against $S$. aureus and S. pyogenes [14]. 
In fact, the azomethine group is found on some marketed drugs e.g., Nifuroxazide(INN) 4 and Thiacetazone 5 are an oral antibiotic, which are used in the treatment of tuberculosis (Figure 1).

Many pyrazole compounds are characterized by their biological activities [15-18], especially antimicrobial activities such as compounds $\mathbf{6}$ and $\mathbf{7}$ exhibit antimicrobial activities [19,20]. (Figure 1)

From the above biological effectiveness of Schiff bases as well as our target to display the biological activities of compounds [21-39], we have reported in this work a series of Schiff bases 14-25 was synthesized by the reaction of 5-amino-pyrazoles 12a-c with aldehydes 13a-d (Figure 1) for evaluation of their antibacterial properties against multi-drug resistant bacteria (MDRB). In addition to this, enzymes assay (staphylococcus aureus DNA gyrase, topoisomerase IV and dihydrofolate reductase enzymes), the molecular modeling study and structure-activity relationship were carried out.<smiles>[R]c1cc(C(=O)N/N=C/c2ccc([N+](=O)[O-])cc2)c2ccccc2n1</smiles>

1<smiles>O=S(=O)(O)c1cc(O)c(/N=C/c2c[nH]c3ccccc23)c2ccccc12</smiles>

2<smiles>C=CC(=N)NS(=O)(=O)c1ccc(/N=C/c2c(O)ccc3ccccc23)cc1</smiles>

3

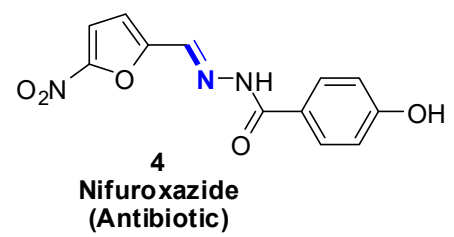<smiles>CC(=O)Nc1ccc(/C=N/NC(N)=S)cc1</smiles>

(Anti-tuberculosis)<smiles>Cc1ccc(-c2nn(-c3ccccc3)c(N)c2N)cc1</smiles>

6<smiles>Cc1nn(-c2ccc(S(N)(=O)=O)cc2)c(-c2ccccc2)c1-c1ccccc1</smiles>

7

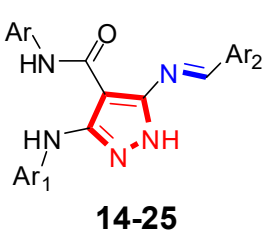

Figure 1. Structures of the antimicrobial Schiff bases 1-3, Nifuroxazide 4, Thiacetazone 5, pyrazole derivatives 6, 7 and the target Schiff bases 14-25.

\section{Results and Discussion}

\subsection{Chemistry}

5-Amino- $1 H$-pyrazoles 12a-c were prepared via the sequence reaction of $N$-substituted cyanoacetamides 8 with 4-methoxyisothicyanate (9), methyl iodide and then with hydrazine hydrate in ethanol refluxing. A series of Schiff bases 14-25 were synthesized by the condensation of 5-aminopyrazoles $\mathbf{1 2} \mathbf{a}-\mathbf{c}$ with aromatic aldehydes $\mathbf{1 3} \mathbf{a}-\mathbf{d}$ and the chemical structures wer confirmed via spectral data (Scheme 1 and Table 1). 
<smiles>N#CCC(=O)N[In]</smiles>

8

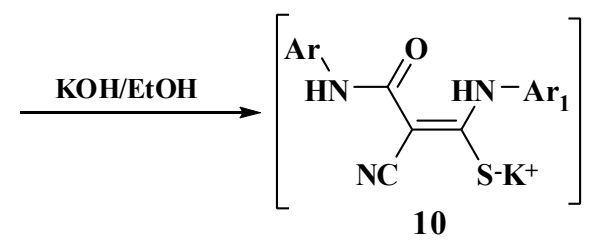
$\mathrm{CH}_{3} \mathrm{I}$<smiles>Nc1[nH]nc(N[Al])c1C(=O)N[Al]</smiles><smiles>CCOC(C)N</smiles><smiles>CC(N[Al+2])=C(C#N)C(=O)N[Al+2]</smiles>

12a-c<smiles>[Y16]C=Nc1[nH]nc(N[Al])c1C(=O)N[Al]</smiles>

14-25

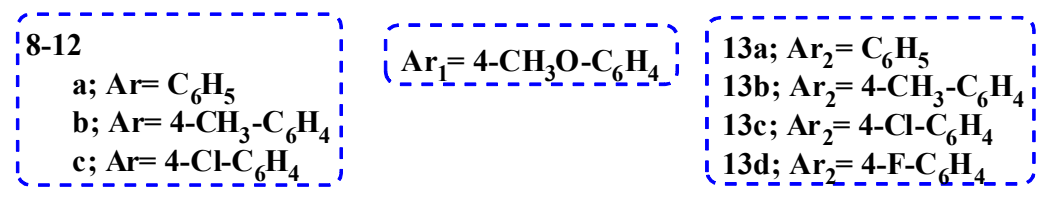

Scheme 1. Synthesis of Schiff bases 14-25.

Table 1. Schiff bases 14-25.

\begin{tabular}{|c|c|c|c|}
\hline Compounds & Ar & $\mathbf{A r}_{1}$ & $\mathrm{Ar}_{2}$ \\
\hline 14 & $\mathrm{Ph}$ & $4-\mathrm{MeOC}_{6} \mathrm{H}_{4^{-}}$ & $\mathrm{Ph}$ \\
\hline 15 & $\mathrm{Ph}$ & $4-\mathrm{MeOC}_{6} \mathrm{H}_{4}-$ & $4-\mathrm{MeC}_{6} \mathrm{H}_{4}-$ \\
\hline 16 & $\mathrm{Ph}$ & $4-\mathrm{MeOC}_{6} \mathrm{H}_{4^{-}}$ & $4-\mathrm{ClC}_{6} \mathrm{H}_{4^{-}}$ \\
\hline 17 & $\mathrm{Ph}$ & $4-\mathrm{MeOC}_{6} \mathrm{H}_{4^{-}}$ & $4-\mathrm{FC}_{6} \mathrm{H}_{4}^{-}$ \\
\hline 18 & $4-\mathrm{MeC}_{6} \mathrm{H}_{4}$ & $4-\mathrm{MeOC}_{6} \mathrm{H}_{4}-$ & $\mathrm{Ph}$ \\
\hline 19 & $4-\mathrm{MeC}_{6} \mathrm{H}_{4}-$ & $4-\mathrm{MeOC}_{6} \mathrm{H}_{4^{-}}$ & $4-\mathrm{MeC}_{6} \mathrm{H}_{4}-$ \\
\hline 20 & $4-\mathrm{MeC}_{6} \mathrm{H}_{4}-$ & $4-\mathrm{MeOC}_{6} \mathrm{H}_{4}-$ & $4-\mathrm{ClC}_{6} \mathrm{H}_{4}^{-}$ \\
\hline 21 & $4-\mathrm{MeC}_{6} \mathrm{H}_{4}{ }^{-}$ & $4-\mathrm{MeOC}_{6} \mathrm{H}_{4^{-}}$ & $4-\mathrm{FC}_{6} \mathrm{H}_{4^{-}}$ \\
\hline 22 & $4-\mathrm{ClC}_{6} \mathrm{H}_{4}^{-}$ & $4-\mathrm{MeOC}_{6} \mathrm{H}_{4^{-}}$ & $\mathrm{Ph}$ \\
\hline 23 & $4-\mathrm{ClC}_{6} \mathrm{H}_{4^{-}}$ & $4-\mathrm{MeOC}_{6} \mathrm{H}_{4^{-}}$ & $4-\mathrm{MeC}_{6} \mathrm{H}_{4}-$ \\
\hline 24 & $4-\mathrm{ClC}_{6} \mathrm{H}_{4^{-}}$ & $4-\mathrm{MeOC}_{6} \mathrm{H}_{4}^{-}$ & $4-\mathrm{ClC}_{6} \mathrm{H}_{4}^{-}$ \\
\hline 25 & $4-\mathrm{ClC}_{6} \mathrm{H}_{4}^{-}$ & $4-\mathrm{MeOC}_{6} \mathrm{H}_{4}^{-}$ & $4-\mathrm{FC}_{6} \mathrm{H}_{4}-$ \\
\hline
\end{tabular}

\subsection{Antibacterial Evaluation}

In vitro antibacterial activities against multi-drug resistant bacteria (MDRB) of Schiff bases 14-25 were performed at botany and microbiology department, Faculty of Science, Al-Azhar University, Cairo, Egypt. The antibacterial potential of 14-25 were investigated towards the multi-drug resistant bacteria (MDRB). The results were summarized as the diameter of the inhibition zones in $\mathrm{mm}$ [40] and minimal inhibitory concentration (MIC, $\mu \mathrm{g} / \mathrm{mL}$ ) [41] values in Table 2. 
Table 2. Minimal inhibitory concentrations in $\mu \mathrm{g} / \mathrm{mL}$ of Schiff bases against multi-drug resistant bacteria (MDRB).

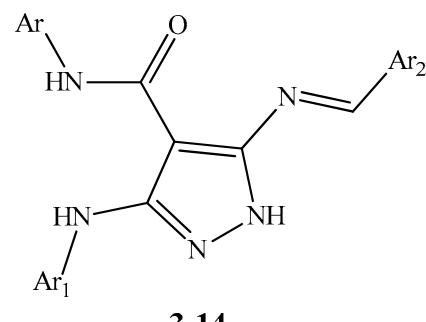

\begin{tabular}{|c|c|c|c|c|c|c|c|c|c|}
\hline \multirow{2}{*}{ Comp. } & \multirow{2}{*}{ Ar } & \multirow{2}{*}{$\mathrm{Ar}_{1}$} & \multirow{2}{*}{$\mathrm{Ar}_{2}$} & \multicolumn{3}{|c|}{ Gram-Positive Bacteria } & \multicolumn{3}{|c|}{ Gram-Negative Bacteria } \\
\hline & & & & Sa & Se & Ef & $\mathrm{Ab}$ & Ecl & Ec \\
\hline 14 & $\mathrm{Ph}$ & $4-\mathrm{MeOC}_{6} \mathrm{H}_{4-}^{-}$ & $\mathrm{Ph}$ & 31.25 & $7.81 *$ & 15.62 & NA & 125 & NA \\
\hline 15 & $\mathrm{Ph}$ & $4-\mathrm{MeOC}_{6} \mathrm{H}_{4}^{-}$ & $4-\mathrm{MeC}_{6} \mathrm{H}_{4}-$ & 62.50 & 15.62 & 31.25 & 62.5 & 62.5 & 125 \\
\hline 16 & $\mathrm{Ph}$ & $4-\mathrm{MeOC}_{6} \mathrm{H}_{4}^{-}$ & $4-\mathrm{ClC}_{6} \mathrm{H}_{4}^{-}$ & 31.25 & $7.81 *$ & 62.5 & $15.62 *$ & 62.5 & 125 \\
\hline 17 & $\mathrm{Ph}$ & $4-\mathrm{MeOC}_{6} \mathrm{H}_{4}^{-}$ & $4-\mathrm{FC}_{6} \mathrm{H}_{4}^{-}$ & 62.5 & 31.25 & NA & 62.5 & 125 & $31.25 *$ \\
\hline 18 & $4-\mathrm{MeC}_{6} \mathrm{H}_{4}-$ & $4-\mathrm{MeOC}_{6} \mathrm{H}_{4}^{-}$ & $\mathrm{Ph}$ & $15.62 *$ & $7.81 *$ & 31.25 & $15.62 *$ & 62.5 & 250 \\
\hline 19 & $4-\mathrm{MeC}_{6} \mathrm{H}_{4}^{-}$ & $4-\mathrm{MeOC}_{6} \mathrm{H}_{4-}^{-}$ & $4-\mathrm{MeC}_{6} \mathrm{H}_{4-}^{-}$ & 31.25 & 15.62 & 15.62 & 62.5 & 125 & 62.5 \\
\hline 20 & $4-\mathrm{MeC}_{6} \mathrm{H}_{4^{-}}$ & $4-\mathrm{MeOC}_{6} \mathrm{H}_{4^{-}}$ & $4-\mathrm{ClC}_{6} \mathrm{H}_{4^{-}}$ & 62.5 & 125 & 250 & NA & NA & NA \\
\hline 21 & $4-\mathrm{MeC}_{6} \mathrm{H}_{4^{-}}$ & $4-\mathrm{MeOC}_{6} \mathrm{H}_{4^{-}}$ & $4-\mathrm{FC}_{6} \mathrm{H}_{4^{-}}$ & 125 & 62.5 & NA & NA & NA & NA \\
\hline 22 & $4-\mathrm{ClC}_{6} \mathrm{H}_{4^{-}}$ & $4-\mathrm{MeOC}_{6} \mathrm{H}_{4}^{-}$ & $\mathrm{Ph}$ & 250 & 125 & 125 & NA & $15.62 *$ & NA \\
\hline 23 & $4-\mathrm{ClC}_{6} \mathrm{H}_{4^{-}}$ & $4-\mathrm{MeOC}_{6} \mathrm{H}_{4^{-}}$ & $4-\mathrm{MeC}_{6} \mathrm{H}_{4}-$ & 31.25 & 15.62 & $7.81 *$ & NA & 62.5 & NA \\
\hline 24 & $4-\mathrm{ClC}_{6} \mathrm{H}_{4^{-}}$ & $4-\mathrm{MeOC}_{6} \mathrm{H}_{4}^{-}$ & $4-\mathrm{ClC}_{6} \mathrm{H}_{4^{-}}$ & 125 & 62.5 & 15.62 & NA & 62.5 & 125 \\
\hline 25 & $4-\mathrm{ClC}_{6} \mathrm{H}_{4}^{-}$ & $4-\mathrm{MeOC}_{6} \mathrm{H}_{4}^{-}$ & $4-\mathrm{FC}_{6} \mathrm{H}_{4^{-}}$ & NA & NA & NA & NA & NA & NA \\
\hline Ciprofloxacin & & & & $7.81 *$ & $15.62 *$ & $7.81 *$ & $15.62 *$ & $15.62 *$ & $7.81 *$ \\
\hline
\end{tabular}

Comp.: Compound. Gram-positive bacteria: Staphylococcus aureus (MRSA, Sa); Staphylococcus epidermis (Se) and Enterococcus faecalis (Ef). Gram-negative bacteria: Acinetobacter baumannii (Ab); Enterobacter cloaca (Ecl) and Escherichia coli (Ec). NA: No Activity. * The most potent compound compared to others.

The result of the minimal inhibitory concentration (MIC) values was in Figure 2. We could see that Schiff base 18 showed very good activity against Staphylococcus aureus (MIC: $15.62 \mu \mathrm{g} / \mathrm{mL}$ ), while compounds 14, 16, 19 and 23 (MIC: $31.25 \mu \mathrm{g} / \mathrm{mL}$ ) showed good activity and Schiff bases 15, 17 and 20 exhibited moderate activity with MIC $=62.5 \mu \mathrm{g} / \mathrm{mL}$. Compounds 14, 16 and 18 (MIC: $7.81 \mu \mathrm{g} / \mathrm{mL}$ ) showed significant activity against Staphylococcus epidermis (Sp) while compounds 15, 19, and 23 showed very good activity (MIC: $15.62 \mu \mathrm{g} / \mathrm{mL}$ ). Schiff base 17 (MIC: $31.25 \mu \mathrm{g} / \mathrm{mL}$ ) showed good activity. In the case of Enterococcus faecalis (Ef), Schiff bases 23 (MIC: $7.81 \mu \mathrm{g} / \mathrm{mL}$ ) showed significant activity and Schiff bases 14, 19 and 24 very good activity (MIC: $15.62 \mu \mathrm{g} / \mathrm{mL}$ ), while compounds 15 and 18 (MIC: $31.25 \mu \mathrm{g} / \mathrm{mL}$ ) showed good activity. Schiff base 16 (MIC: $62.5 \mu \mathrm{g} / \mathrm{mL}$ ) showed moderate activity.

In the case of Acinetobacter baumannii (Ab), Schiff bases 16 and 18 showed very good activity (MIC: $15.62 \mu \mathrm{g} / \mathrm{mL}$ ), while compounds 15, 17, and 19 (MIC: $62.5 \mu \mathrm{g} / \mathrm{mL}$ ) showed moderate activity.

Schiff base 22 displayed very good activity (MIC: $15.62 \mu \mathrm{g} / \mathrm{mL}$ ) against Enterobacter cloaca (Ecl), while compounds 15, 16, 18, 23 and 24 (MIC: $62.5 \mu \mathrm{g} / \mathrm{mL}$ ) showed moderate activity.

Schiff base 17 (MIC: $31.25 \mu \mathrm{g} / \mathrm{mL}$ ) showed good activity, while 19 (MIC: $62.5 \mu \mathrm{g} / \mathrm{mL}$ ) showed moderate activity against Escherichia coli (Ec). 

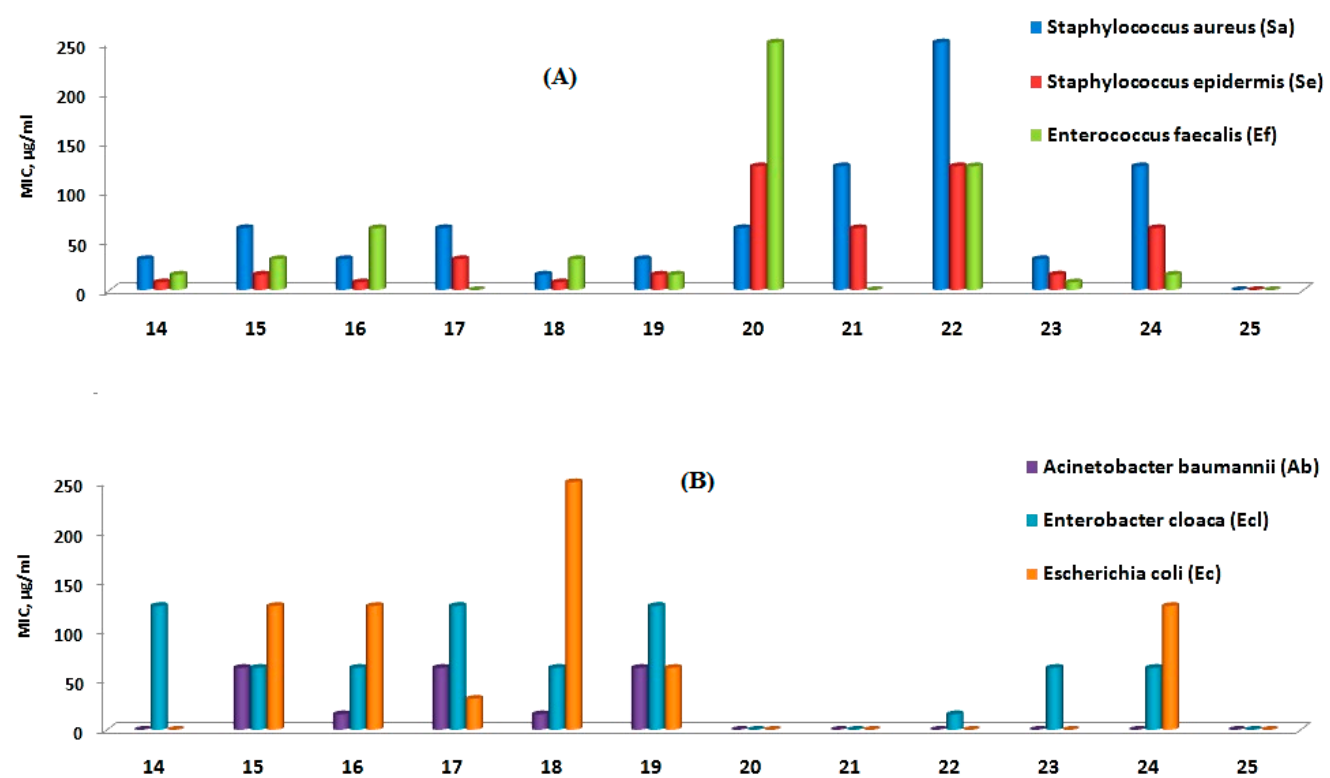

Figure 2. Minimal inhibitory concentrations (MIC, $\mu \mathrm{g} / \mathrm{mL}$ ) of Schiff bases 14-25 against multi-drug resistant bacteria (A) Gram-positive bacteria, (B) Gram-negative bacteria.

\subsection{Structure-Activity Relationship (SAR)}

From the results of antibacterial activities of Schiff bases 14-25 against multi-drug resistant bacteria, it was found that, in case of $\mathrm{Ar}=\mathrm{Ph}, 4-\mathrm{CH}_{3}-\mathrm{C}_{6} \mathrm{H}_{4}$ or $4-\mathrm{Cl}_{-}-\mathrm{C}_{6} \mathrm{H}_{4}$, the order of antibacterial activity $\mathrm{Ar}_{2}$ $=\mathrm{Ph}>4-\mathrm{CH}_{3}-\mathrm{C}_{6} \mathrm{H}_{4}$ and $\mathrm{Ar}_{2}=4-\mathrm{Cl}-\mathrm{C}_{6} \mathrm{H}_{4}>4-\mathrm{F}_{-} \mathrm{C}_{6} \mathrm{H}_{4}$ was observed upon screening of Schiff bases 14-25 against the screening organisms (Figure 3 ).

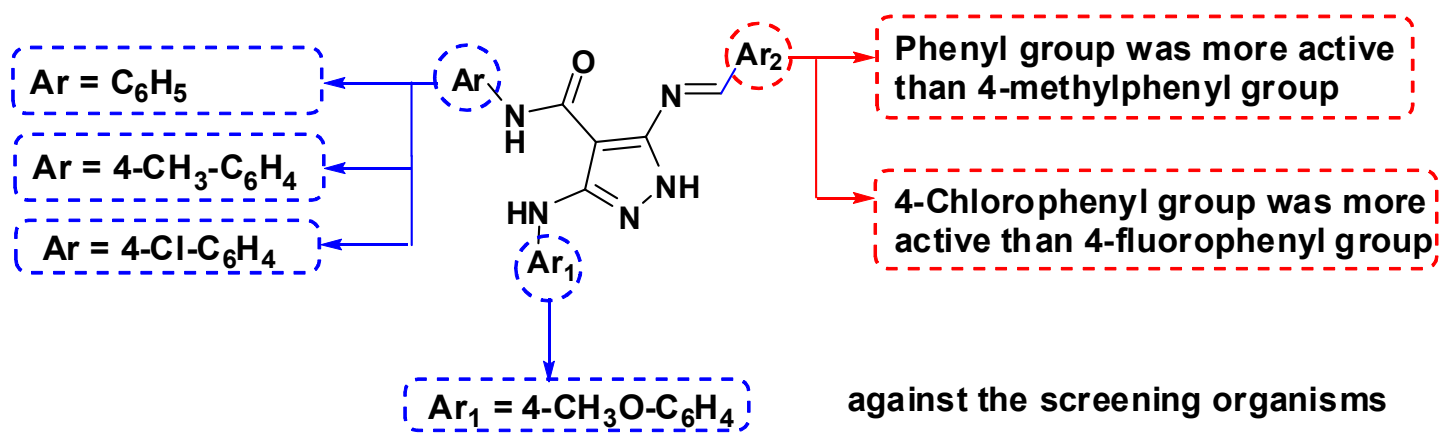

Figure 3. A brief Structure activity relationship (SAR) study of Schiff bases 14-25.

\subsection{In Silico ADMET Properties of Schiff Bases 14-25}

The physical properties and the ADMET parameters (absorption, distribution, metabolism, excretion and toxicity) of Schiff bases 14-25 were computed using the freely accessible web server Swiss ADME (http://swissadme.ch/index.php\#undefined). The results of in silico ADMET properties of Schiff bases 14-25 are listed in Table 3.

The molecular weight (MW), the number of hydrogen bond acceptors (nHBA), donors (nHBD), the number of rotatable bonds (nRB) and the topological polar surface area (TPSA) for all the Schiff bases were in accordance with the Lipinski's rule of five. The lipophilicity property (expressed as MLogP $\leq 4.15$ ) was in the range for all the Schiff bases excluding 20, 21, 23, 24 and 25. The highly lipophilic character (MLogP > 4.15) of the compounds 20, 21, 23, 24 and 25 may be because of the presence of chloro or fluoro atoms in their structures which may make difficult their transport through the blood strain [42]. 
Table 3. In silico prediction of Lipinski's rule of five for the Schiff bases 14-25.

\begin{tabular}{|c|c|c|c|c|c|c|c|}
\hline Comp. & $\mathrm{MW}^{\mathrm{a}}$ & $M \log \mathrm{P}^{\mathrm{b}}$ & $n \mathrm{HBA}^{\mathrm{c}}$ & nHBD $^{d}$ & $n \mathrm{RB}^{\mathrm{e}}$ & TPSA $^{f}$ & $\mathbf{n}_{\text {violations }} \mathrm{g}$ \\
\hline Rule & $<500$ & $\leq 4.15$ & $\leq \mathbf{1 0}$ & $\leq 5$ & $\leq \mathbf{1 0}$ & $<160 \AA^{2}$ & 0 \\
\hline 14 & 411.46 & 3.65 & 4 & 3 & 8 & 91.40 & 0 \\
\hline 15 & 425.48 & 3.86 & 4 & 3 & 8 & 91.40 & 0 \\
\hline 16 & 445.90 & 4.13 & 4 & 3 & 8 & 91.40 & 0 \\
\hline 17 & 429.45 & 4.02 & 5 & 3 & 8 & 91.40 & 0 \\
\hline 18 & 425.48 & 3.86 & 4 & 3 & 8 & 91.40 & 0 \\
\hline 19 & 439.51 & 4.06 & 4 & 3 & 8 & 91.40 & 0 \\
\hline 20 & 459.93 & 4.33 & 4 & 3 & 8 & 91.40 & 1 \\
\hline 21 & 443.47 & 4.23 & 5 & 3 & 8 & 91.40 & 1 \\
\hline 22 & 445.90 & 4.13 & 4 & 3 & 8 & 91.40 & 0 \\
\hline 23 & 459.93 & 4.33 & 4 & 3 & 8 & 91.40 & 1 \\
\hline 24 & 480.35 & 4.60 & 4 & 3 & 8 & 91.40 & 1 \\
\hline 25 & 463.89 & 4.50 & 5 & 3 & 8 & 91.40 & 1 \\
\hline
\end{tabular}

${ }^{\mathrm{a}}$ Molecular Weight; ${ }^{\mathrm{b}}$ Calculated Lipophillicity (MLog $\left.P_{\mathrm{o} / \mathrm{w}}\right) ;{ }^{\mathrm{c}}$ Number of Hydrogen Bond Acceptor; ${ }^{\mathrm{d}}$ Number of Hydrogen Bond Donor; ${ }^{\mathrm{e}}$ Number of Rotatable Bond; ${ }^{\mathrm{f}}$ Topological Polar Surface Area; $\mathrm{g}$ Violations from Lipinski's Rule.

\subsection{In Vitro Kinase Assessment}

In an effort to study the preliminary mechanism of the compound $\mathbf{1 8}$ with potent antibacterial activity, an enzyme inhibitory assay was performed towards staphylococcus aureus DNA gyrase, topoisomerase IV and dihydrofolate reductase enzymes. The obtained results were presented as $\mathrm{IC}_{50}$ and provided in Table 4 using suitable positive controls, Ciprofloxacin and Methotrexate.

Table 4. Inhibitory assessment ( $\mathrm{IC}_{50}$ in $\mu \mathrm{M}$ ) of compound $\mathbf{1 8}$ on Staphylococcus aureus DNA gyrase, Topoisomerase IV and Dihydrofolate reductase enzymes.

\begin{tabular}{cccc}
\hline \multirow{2}{*}{ Compound } & \multicolumn{3}{c}{ IC $_{\mathbf{5 0}}$ (Mean \pm SEM) $(\mu \mathrm{M})$} \\
\cline { 2 - 4 } & DNA Gyrase & Topoisomerase IV & DHFR \\
\hline $\mathbf{1 8}$ & $1.68 \pm 0.10$ & $74.55 \pm 1.20$ & $0.08 \pm 1.15$ \\
Ciprofloxacin & $1.51 \pm 0.18$ & $24.14 \pm 1.01$ & - \\
Methotrexate & - & - & $0.14 \pm 1.07$ \\
\hline
\end{tabular}

$\mathrm{IC}_{50}$ : Compound concentration required to inhibit the enzyme viability by $50 \%$, SEM = standard error mean; each value is the mean of three values.

From Table 4, it was observed that compound $\mathbf{1 8}$ demonstrated a nearly equipotent inhibitory activity towards DNA gyrase and weak activity against topoisomerase IV in comparison with the reference Ciprofloxacin $\left(\mathrm{IC}_{50}=1.68 \pm 0.10,74.55 \pm 1.20,1.51 \pm 0.18\right.$ and $24.14 \pm 1.01 \mu \mathrm{M}$, respectively). Moreover, compound 18 revealed two folds increase in the suppression effect towards dihydrofolate reductase comparing with Methotrexate $\left(\mathrm{IC}_{50}=0.08 \pm 1.15\right.$ and $0.14 \pm 1.07 \mu \mathrm{M}$, respectively).

\subsection{Molecular Docking Study}

Molecular docking studies concerning the in vitro kinase assessment were performed to understand the interactions of compound $\mathbf{1 8}$ with Staphylococcus aureus DNA gyrase and Dihydrofolate reductase enzymes. The binding modes of compounds 18 were investigated through using Molecular Operating Environment $\left(\mathrm{MOE}^{\circledR}\right)$ 2008.10 [43]. The X-ray crystal structures of Staphylococcus aureus DNA gyrase (PDB code: $2 X C T$ ) [44] and dihydrofolate reductase (PDB code: 1DLS) [45] were downloaded from the Protein Data Bank. In the present study, the proposed docking algorithms were initially validated by self-docking of the co-crystallized ligands Ciprofloxacin and Methotrexate to each of the aforementioned targets and exhibited root mean square deviation (RMSD) values of 0.86 and 
$0.92 \AA$, respectively. Subsequently, docking procedures have been achieved for compound 18 and the corresponding 2D and 3D representations of the binding modes are illustrated in Figures 4 and 5.

As shown in Figure 4, compound 18 linked tightly with amino acid residues of Staphylococcus aureus DNA gyrase. There were arene-arene interactions established between the centroids of DG9 and 4-methoxyphenyl, and arene-cation interactions between the centroid of benzylidene at p-5 of pyrazole moiety and Arg458. Moreover, the oxygen of 4-methoxy group supported the binding with two hydrogen bonds with the sidechain of Ser1084 (distance: 2.36 and $3.27 \AA$ ).
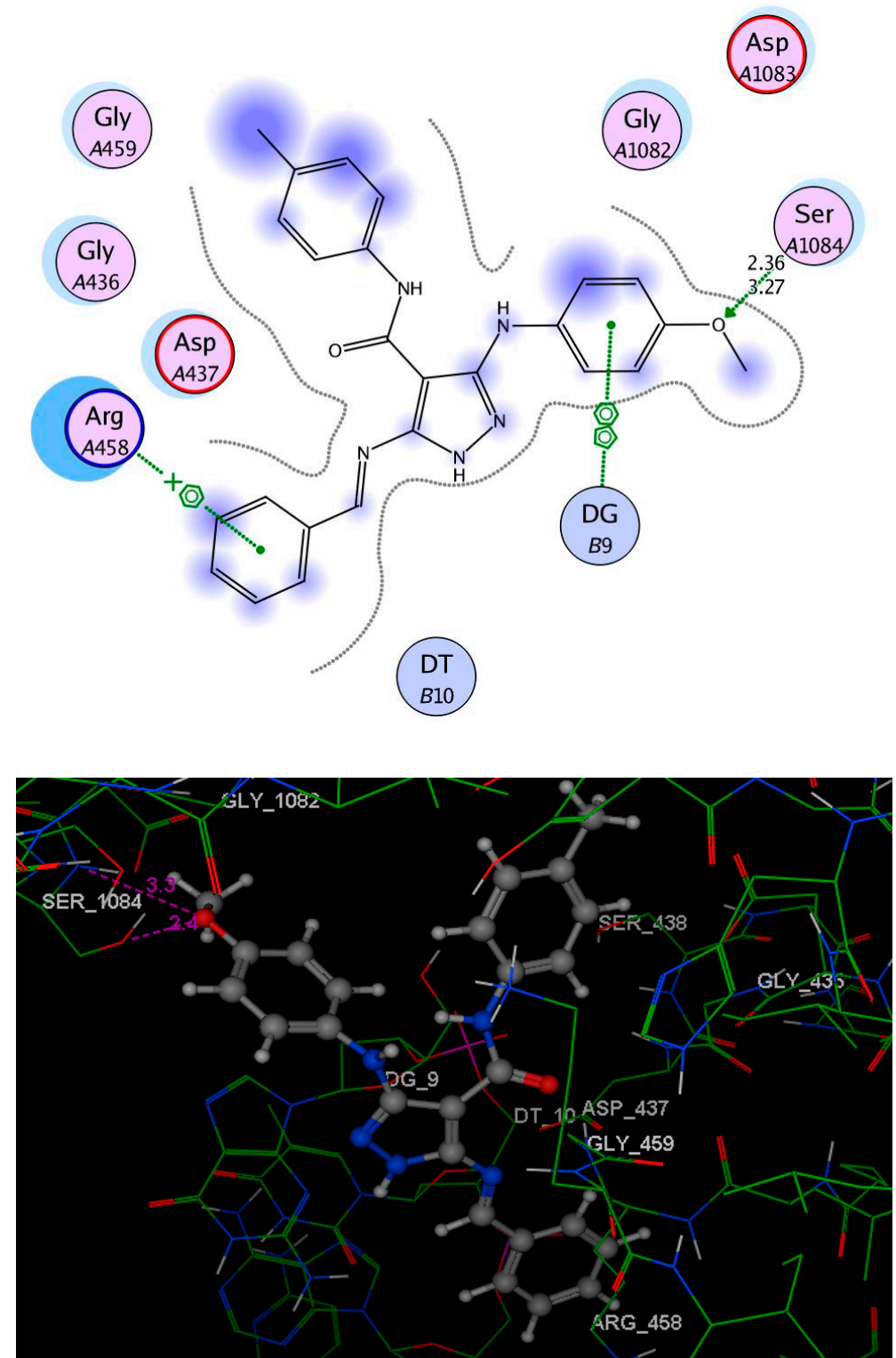

Figure 4. 2D and 3D interaction diagrams of compound 18 with Staphylococcus aureus DNA gyrase (PDB code: 2XCT) (hydrogen bonds are illustrated as arrows, $\mathrm{C}$ atoms are colored gray, $\mathrm{N}$ blue, and $\mathrm{O}$ red).

Considering the binding interaction of compound 18 with dihydrofolate reductase illustrated in Figure 5, it was noticed that N1 and N2 of pyrazole scaffold participated by two hydrogen bonds with the sidechain and the backbone of Ser59 (distance: 2.62 and $2.34 \AA$, respectively). Additionally, the tolyl moiety formed arene-arene interaction with the centroid of Ph34 passing through Ph31. 

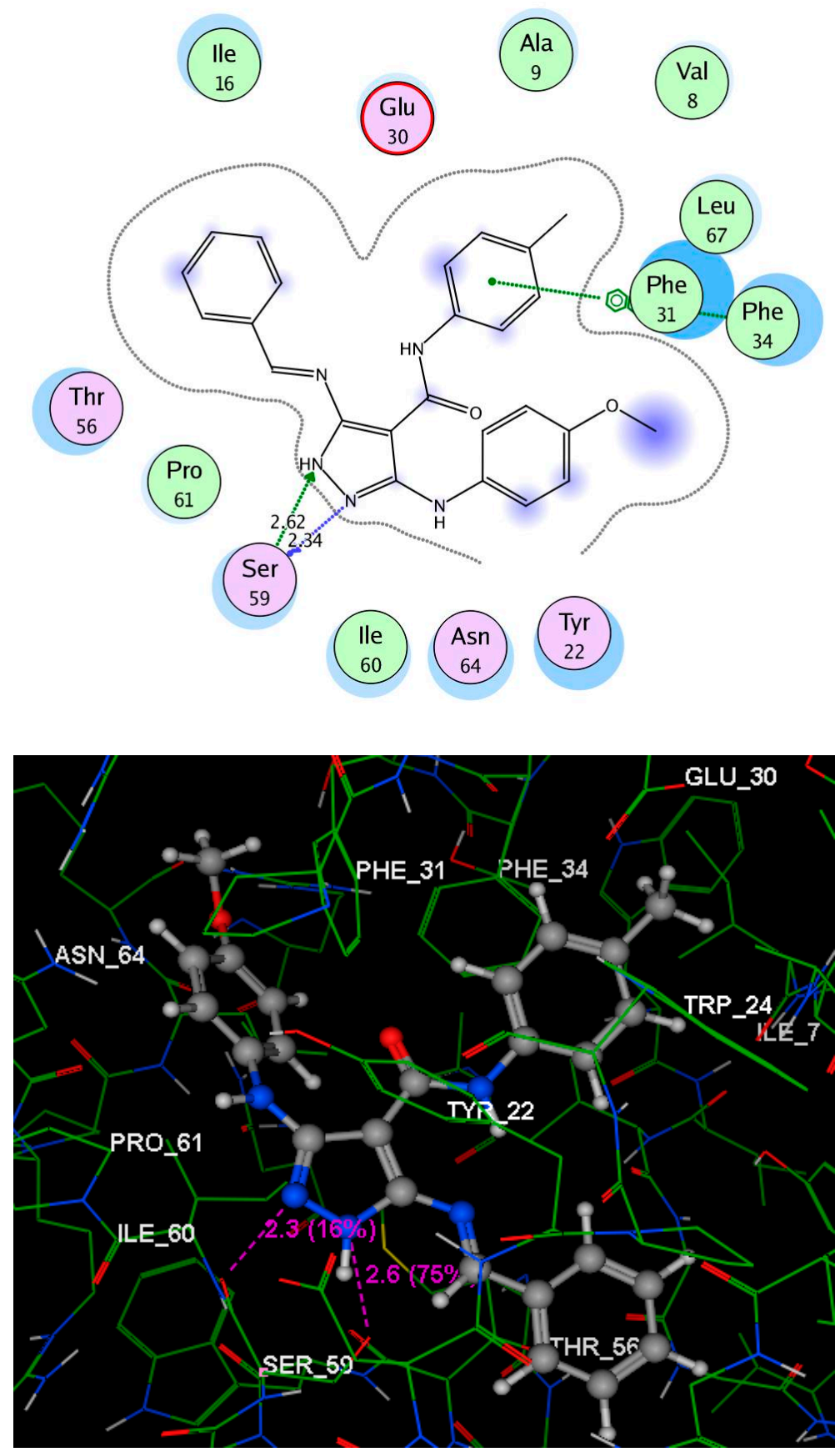

Figure 5. 2D and 3D interaction diagrams of compound 18 with DHFR (PDB code: 1DLS) (hydrogen bonds are illustrated as arrows, $\mathrm{C}$ atoms are colored gray, $\mathrm{N}$ blue, and $\mathrm{O}$ red).

\section{Materials and Methods}

\subsection{Chemicals}

5-Amino-1H-pyrazoles 12a-c [46] and Schiff bases 14-25 [47] were prepared according to the reported procedure.

The chemical structures of Schiff bases 14-25 was confirmed via spectral data [47]. 


\subsection{In Vitro Antibacterial Evaluation}

\subsubsection{Test Microorganisms}

The synthesized compounds, Schiff bases 14-25, were in vitro evaluation of their antibacterial properties against multi-drug resistant bacteria (MDRB). Examples of Gram-positive bacteria are Staphylococcus aureus (MRSA, Sa), Staphylococcus epidermis (Sp), and Enterococcus faecalis (Ef). Examples of Gram-negative bacteria are Acinetobacter baumannii (Ab), Enterobacter cloaca (Ecl), and Escherichia coli (Ec). All the tested strain was identified by Vitek ${ }^{\circledR} 2$ system. The multi-drug resistant to antibiotics such as Ampicillin, Cephalexin, Colisin, Ipemenem, and Meropenem was verified.

\subsubsection{Antibacterial Activity}

In vitro antibacterial activities were performed at botany and microbiology department, Faculty of Science, Al-Azhar University, Cairo, Egypt. The antibacterial potential of Schiff bases 14-25 were investigated towards multi-drug resistant bacteria (MDRB) and expressed as the diameter of the inhibition zones according to the agar plate diffusion method [40].

\subsubsection{Minimum Inhibitory Concentration (MIC) of the Active Compounds}

The minimal inhibitory concentration (MIC) of the most potent Schiff bases was determined by the conventional paper disk diffusion method [41].

\subsection{In Vitro Kinase Assessment}

The in vitro enzyme inhibition determination for compound 18 was carried out in the confirmatory diagnostic unit, Vacsera, Egypt. The evaluation performed profiling of compound $\mathbf{1 8}$ against Staphylococcus aureus DNA gyrase, topoisomerase IV, and dihydrofolate reductase enzymes using Ciprofloxacin and Methotrexate as reference drugs according to the previously reported method $[45,48]$.

\subsection{Molecular Docking Study}

Automated docking studies were carried out using Molecular Operating Environment $\left(\mathrm{MOE}^{\circledR}\right)$ 2008.10 [43]. The crystal structures of Staphylococcus aureus DNA gyrase (PDB code: 2XCT) [44] and dihydrofolate reductase (PDB code: 1DLS) [45] complexed with Ciprofloxacin and Methotrexate, respectively were retrieved from the RCSB Protein Data Bank (http://www.rcsb.org/pdb/home/home.do).

\section{Conclusions}

In this work, a series of Schiff bases 14-25 were synthesized by the condensation of 5-aminopyrazoles 12a-c with aromatic aldehydes 13a-d, with high yields for evaluation of their in vitro antibacterial activities against multi-drug resistant bacteria (MDRB). In general, most of Schiff bases 14-25 displayed better antibacterial activity. In addition, a positive result of kinase inhibition was implicated by molecular docking study against Staphylococcus aureus DNA gyrase and dihydrofolate reductase enzymes. Furthermore, drug-likeness data revealed that the studied compounds fulfill Lipinski's rule requirements and have good drug score values. These preliminary results of Schiff bases against multi-drug resistant bacteria (MDRB) could provide an exceptional model that may lead to the discovery of new antibiotics by derivatization or modification.

Author Contributions: A.S.H. and G.O.M. formulated the research idea; A.S.H., G.O.M., A.M.N. and M.A.A.-O. carried out the experimental and interpreted the data; A.A.A. performed the antibacterial screening; E.S.N. performed the enzyme assay and molecular docking. All authors have prepared the manuscript and approved the final manuscript.

Funding: The authors are grateful to the Deanship of Scientific Research, King Saud University for funding through Vice Deanship of Scientific Research Chairs. 
Acknowledgments: The authors are grateful to the Deanship of Scientific Research, King Saud University for funding through Vice Deanship of Scientific Research Chairs.

Conflicts of Interest: The authors declare no conflicts of interest.

\section{References}

1. Asadi, Z.; Nasrollahi, N. The effect of metal and substituent on DNA binding, cleavage activity, and cytotoxicity of new synthesized Schiff base ligands and Zn(II) complex. J. Mol. Struct. 2017, 1147, 582-593. [CrossRef]

2. Jamshidvand, A.; Sahihi, M.; Mirkhani, V.; Moghadam, M.; Mohammadpoor-Baltork, I.; Tangestaninejad, S.; Rudbari, H.A.; Kargar, H.; Keshavarzi, R.; Gharaghani, S. Studies on DNA binding properties of new Schiff base ligands using spectroscopic, electrochemical and computationalmethods: Influence of substitutions on DNA-binding. J. Mol. Liq. 2018, 253, 61-71. [CrossRef]

3. Zhao, F.; Wang, W.; Lu, W.; Xu, L.; Yang, S.; Cai, X.-M.; Zhou, M.; Lei, M.; Ma, M.; Xu, H.-J.; et al. High anticancer potency on tumor cells of dehydroabietylamine Schiff-base derivatives and a copper(II) complex. Eur. J. Med. Chem. 2018, 146, 451-459. [CrossRef] [PubMed]

4. Sangeeta, S.; Ahmad, K.; Noorussabah, N.; Bharti, S.; Mishra, M.K.; Sharma, S.R.; Choudhary, M. Synthesis, crystal structures, molecular docking and urease inhibition studies of $\mathrm{Ni}$ (II) and $\mathrm{Cu}$ (II) Schiff base complexes. J. Mol. Struct. 2018, 1156, 1-11. [CrossRef]

5. Demirci, S.; Doğan, A.; Türkmen, N.B.; Telci, D.; Rizvanov, A.A.; Şahin, F. Schiff base-Poloxamer P85 combination demonstrates chemotherapeutic effect on prostate cancer cells in vitro. Biomed. Pharmacother. 2017, 86, 492-501. [CrossRef] [PubMed]

6. Rauf, A.; Shah, A.; Khan, A.A.; Shah, A.H.; Abbasi, R.; Qureshi, I.Z.; Ali, S. Synthesis, pH dependent photometric and electrochemical investigation, redox mechanism and biological applications of novel Schiff base and its metallic derivatives. Spectrochim. Acta A Mol. Biomol. Spectrosc. 2017, 176, 155-167. [CrossRef] [PubMed]

7. Liu, Y.-T.; Sheng, J.; Yin, D.-W.; Xin, H.; Yang, X.-M.; Qiao, Q.-Y.; Yang, Z.-J. Ferrocenyl chalcone-based Schiff bases and their metal complexes: Highly efficient, solvent-free synthesis, characterization, biological research. J. Organomet. Chem. 2018, 856, 27-33. [CrossRef]

8. Raman, N.; Raja, J.D.; Sakthivel, A. Synthesis, spectral characterization of Schiff base transition metal complexes: DNA cleavage and antimicrobial activity studies. J. Chem. Sci. 2007, 119, 303-310. [CrossRef]

9. Iftikhar, B.; Javed, K.; Khan, M.S.U.; Akhter, Z.; Mirza, B.; Mckee, V. Synthesis, characterization and biological assay of Salicylaldehyde Schiff base Cu(II) complexes and their precursors. J. Mol. Struct. 2018, 1155, 337-348. [CrossRef]

10. Fekri, R.; Salehi, M.; Asadi, A.; Kubicki, M. Synthesis, characterization, anticancer and antibacterial evaluation of Schiff base ligands derived from hydrazone and their transition metal complexes. Inorg. Chim. Acta 2019, 484, 245-254. [CrossRef]

11. Tamer, A.M.; Hassan, M.A.; Omer, M.A.; Baset, W.M.A.; Hassan, M.E.; El-Shafeey, M.E.A.; Mohy Elding, M.S. Synthesis, characterization and antimicrobial evaluation of two aromatic chitosan Schiff base derivatives. Process Biochem. 2016, 51, 1721-1730. [CrossRef]

12. Bodke, Y.D.; Shankerrao, S.; Kenchappa, R.; Telkar, S. Synthesis, Antibacterial and Antitubercular Activity of Novel Schiff Bases of 2-(1-Benzofuran-2-yl)quinoline-4-carboxylic Acid Derivatives1. Russ. J. Gen. Chem. 2017, 87, 1843-1849. [CrossRef]

13. Sinha, D.; Tiwari, A.K.; Singh, S.; Shukla, G.; Mishra, P.; Chandra, H.; Mishra, A.K. Synthesis, characterization and biological activity of Schiff base analogues of indole-3-carboxaldehyde. Eur. J. Med. Chem. 2008, 43, 160-165. [CrossRef] [PubMed]

14. Mondal, S.; Mandal, S.M.; Mondal, T.K.; Sinha, C. Spectroscopic characterization, antimicrobial activity, DFT computation and docking studies of sulfonamide Schiff bases. J. Mol. Struct. 2017, 1127, 557-567. [CrossRef]

15. Hassan, A.S.; Hafez, T.S.; Ali, M.M.; Khatab, T.K. Design, synthesis and cytotoxic activity of some new pyrazolines bearing benzofuran and pyrazole moieties. Res. J. Pharm. Biol. Chem. Sci. 2016, 7, 417-429.

16. Hassan, A.S.; Mady, M.F.; Awad, H.M.; Hafez, T.S. Synthesis and antitumor activity of some new pyrazolo [1,5-a]pyrimidines. Chin. Chem. Lett. 2017, 28, 388-393. [CrossRef] 
17. Abd El Razik, H.A.; Badr, M.H.; Attia, H.A.; Mouneir, S.M.; Abu-Serie, M.M. Benzodioxole-pyrazole hybrids as anti-inflammatory and analgesic agents with COX-1,2/5-LOX inhibition and antioxidant potential. Arch. Pharm. Chem. Life Sci. 2017, 350, e1700026. [CrossRef]

18. Hassan, A.S.; Hafez, T.S.; Osman, S.A.M.; Ali, M.M. Synthesis and in vitro cytotoxic activity of novel pyrazolo[1,5-a]pyrimidines and related Schiff bases. Turk. J. Chem. 2015, 39, 1102-1113. [CrossRef]

19. Rizk, H.F.; EI-Badawi, M.A.; Ibrahim, S.A.; EI-Borai, M.A. Cyclization of 4,5-diamino pyrazole derivatives and their antibacterial activities. Chin. J. Chem. 2011, 29, 1451-1459. [CrossRef]

20. Sharshira, E.M.; Hamada, N.M.M. Synthesis and Antimicrobial Evaluation of Some Pyrazole Derivatives. Molecules 2012, 17, 4962-4971. [CrossRef]

21. El-Naggar, M.; Hassan, A.S.; Awad, H.M.; Mady, M.F. Design, Synthesis and Antitumor Evaluation of Novel Pyrazolopyrimidines and Pyrazoloquinazolines. Molecules 2018, 23, 1249. [CrossRef] [PubMed]

22. Hassan, A.S.; Hafez, T.S. Antimicrobial Activities of Ferrocenyl Complexes: A Review. J. App. Pharm. Sci. 2018, 8, 156-165.

23. Hassan, A.S.; Masoud, D.M.; Sroor, F.M.; Askar, A.A. Synthesis and biological evaluation of pyrazolo[1,5-a]pyrimidine-3-carboxamide as antimicrobial agents. Med. Chem. Res. 2017, 26, 2909-2919. [CrossRef]

24. Hassan, A.S.; Moustafa, G.O.; Awad, H.M. Synthesis and in vitro anticancer activity of pyrazolo[1,5-a]pyrimidines and pyrazolo[3,4- $d][1,2,3]$ triazines. Synth. Commun. 2017, 47, 1963-1972. [CrossRef]

25. Khatab, T.K.; Hassan, A.S.; Hafez, T.S. $\mathrm{V}_{2} \mathrm{O}_{5} / \mathrm{SiO}_{2}$ as an efficient catalyst in the synthesis of 5-aminopyrazole derivatives under solvent free condition. Bull. Chem. Soc. Ethiop. 2019, 33, 135-142. [CrossRef]

26. Magd-El-Din, A.A.; Mousa, H.A.; Labib, A.A.; Hassan, A.S.; Abd El-All, A.S.; Ali, M.M.; El-Rashedy, A.A.; El-Desoky, A.H. Benzimidazole-Schiff bases and their complexes: Synthesis, anticancer activity and molecular modeling as Aurora kinase inhibitor. Z. Naturforsch. C 2018, 73, 465-478. [CrossRef] [PubMed]

27. Hassan, A.S.; Moustafa, G.O.; Askar, A.A.; Naglah, A.M.; Al-Omar, M.A. Synthesis and antibacterial evaluation of fused pyrazoles and Schiff bases. Synth. Commun. 2018, 48, 2761-2772. [CrossRef]

28. Abd El-All, A.S.; Hassan, A.S.; Osman, S.A.; Yosef, H.A.A.; Abdel-Hady, W.H.; El-Hashash, M.A.; Atta-Allah, S.R.; Ali, M.M.; El Rashedy, A.A. Synthesis, characterization and biological evaluation of new fused triazine derivatives based on 6-methyl-3-thioxo-1,2,4-triazin-5-one. Acta Pol. Pharm. 2016, 73, 79-92. [PubMed]

29. Hassan, A.S.; Osman, S.A.; Hafez, T.S. 5-Phenyl-2-furaldehyde: Synthesis, Reactions and Biological Activities. Egypt. J. Chem. 2015, 58, 113-139.

30. Osman, S.A.; Mousa, H.A.; Yosef, H.A.A.; Hafez, T.S.; El-Sawy, A.A.; Abdallah, M.M.; Hassan, A.S. Synthesis, characterization and cytotoxicity of mixed ligand $\mathrm{Mn}(\mathrm{II}), \mathrm{Co}(\mathrm{II})$ and $\mathrm{Ni}(\mathrm{II})$ complexes. J. Serb. Chem. Soc. 2014, 79, 953-964. [CrossRef]

31. Hafez, T.S.; Osman, S.A.; Yosef, H.A.A.; Abd El-All, A.S.; Hassan, A.S.; El-Sawy, A.A.; Abdallah, M.M.; Youns, M. Synthesis, structural elucidation and in vitro antitumor activities of some pyrazolopyrimidines and Schiff bases derived from 5-amino-3-(arylamino)-1H-pyrazole-4-carboxamides. Sci. Pharm. 2013, 81, 339-357. [CrossRef] [PubMed]

32. Osman, S.A.; Yosef, H.A.A.; Hafez, T.S.; El-Sawy, A.A.; Mousa, H.A.; Hassan, A.S. Synthesis and antibacterial activity of some novel chalcones, pyrazoline and 3-cyanopyridine derivatives based on khellinone as well as $\mathrm{Ni}(\mathrm{II}), \mathrm{Co}(\mathrm{II})$ and Zn(II) complexes. Aust. J. Basic Appl. Sci. 2012, 6, 852-863.

33. Elgemeie, G.H.; Elsayed, S.H.; Hassan, A.S. Design and synthesis of the first thiophene thioglycosides. Synth. Commun. 2009, 39, 1781-1792. [CrossRef]

34. Elgemeie, G.H.; Elsayed, S.H.; Hassan, A.S. Direct route to a new class of acrylamide thioglycosides and their conversions to pyrazole derivatives. Synth. Commun. 2008, 38, 2700-2706. [CrossRef]

35. Moustafa, G.O.; Khalaf, H.; Naglah, A.; Al-Wasidi, A.; Al-Jafshar, N.; Awad, H. The Synthesis of Molecular Docking Studies, In Vitro Antimicrobial and Antifungal Activities of Novel Dipeptide Derivatives Based on N-(2-(2-Hydrazinyl-2-oxoethylamino)-2-oxoethyl)-nicotinamide. Molecules 2018, 23, 761. [CrossRef]

36. Al-Salem, H.S.A.; Naglah, A.M.; Moustafa, G.O.; Mahmoud, A.Z.; Al-Omar, M.A. Synthesis of Novel Tripeptides Based on Dibenzofuran-2-Sulfonyl-[Aromatic and Hydroxy Aromatic Residues]: Towards Antimicrobial and Antifungal Agents. J. Comput. Theor. Nanosci. 2017, 14, 3958-3966. [CrossRef] 
37. Naglah, A.M.; Moustafa, G.O.; Al-Omar, M.A.; Al-Salem, H.S.A.; Hozzein, W.N. Synthesis, Characterization andInVitroAntimicrobial Investigation of Novel Amino Acids and Dipeptides Based on Dibenzofuran-2-Sulfonyl-Chloride. J. Comput. Theor. Nanosci. 2017, 14, 3183-3190. [CrossRef]

38. Abo-Ghalia, M.H.; Moustafa, G.O.; Alwasidi, A.S.; Naglah, A.M. Cytotoxic Investigation of Isophthaloyl Cyclopentapeptides. Lat. Am. J. Pharm. 2017, 36, 1957-1962.

39. Moustafa, G.O.; El-Sawy, A.A.; Abo-Ghalia, M.H. Synthesis of novel cyclopeptide candidates: I-cyclo-[N $\alpha$ _-isophthaloyl-bis-(Glycine-amino acid)-L-lysine] derivatives with expected anticancer activity. Egypt. J. Chem. 2013, 56, 473-494.

40. Cappuccino, J.G.; Sherman, N. Microbiology, Laboratory Manual; Pearson Education, Inc.: New Delhi city, India, 2004; pp. 282-283.

41. Cooper, K. The Theory of Antibiotic Inhibition Zones. In Analytical Microbiology; Academic press: New York, NY, USA; London, UK, 1963; pp. 1-85.

42. Lipinski, C.A.; Lombardo, F.; Dominy, B.W.; Feeney, P.J. Experimental and computational approaches to estimate solubility in drug discovery and development settings. Adv. Drug Deliv. Rev. 2001, 46, 3-26. [CrossRef]

43. Amr, A.E.; Abo-Ghalia, M.H.; Moustafa, G.O.; Al-Omar, M.A.; Nossier, E.S.; Elsayed, E.A. Design, synthesis and docking studies of novel macrocyclic pentapeptides as anticancer multi-targeted kinase inhibitors. Molecules 2018, 23, 2416. [CrossRef] [PubMed]

44. Bax, B.D.; Chan, P.F.; Eggleston, D.S.; Fosberry, A.; Gentry, D.R.; Gorrec, F.; Giordano, I.; Hann, M.M.; Hennessy, A.; Hibbs, M.; et al. Type IIA topoisomerase inhibition by a new class of antibacterial agents. Nature 2010, 466, 935-940. [CrossRef] [PubMed]

45. El-Naggar, M.; Sallam, H.A.; Shaban, S.S.; Abdel-Wahab, S.S.; Amr, A.E.; Azab, M.E.; Nossier, E.S.; Al-Omar, M.A. Design, Synthesis, and Molecular Docking Study of Novel Heterocycles Incorporating 1,3,4-Thiadiazole Moiety as Potential Antimicrobial and Anticancer Agents. Molecules 2019, 24, 1066. [CrossRef] [PubMed]

46. Hassan, A.S.; Hafez, T.S.; Osman, S.A. Synthesis, characterization, and cytotoxicity of some new 5-aminopyrazole and pyrazolo[1,5-a]pyrimidine derivatives. Sci. Pharm. 2015, 83, 27-39. [CrossRef] [PubMed]

47. Hassan, A.S.; Awad, H.M.; Magd-El-Din, A.A.; Hafez, T.S. Synthesis and in vitro antitumor evaluation of novel Schiff bases. Med. Chem. Res. 2018, 27, 915-927. [CrossRef]

48. Othman, I.M.M.; Gad-Elkareem, M.A.M.; El-Naggar, M.; Nossier, E.S.; Amr, A.E. Novel phthalimide based analogues: Design, synthesis, biological evaluation, and molecular docking studies. J. Enzyme Inhib. Med. Chem. 2019, 34, 1259-1270. [CrossRef] [PubMed]

Sample Availability: Samples of the compounds are not available from the authors.

(C) 2019 by the authors. Licensee MDPI, Basel, Switzerland. This article is an open access article distributed under the terms and conditions of the Creative Commons Attribution (CC BY) license (http://creativecommons.org/licenses/by/4.0/). 